Казарин И.Е.,

Магистрант, НГПУ им. К. Минина

Крайнова О.С.,

К.э.н., доч, зав. каф. туризма

Филиал ЧОУВО «МУ им. С.Ю. Витте»

\title{
РОЛЬ АССОЦИАЦИИ «ТУРПОМОЩЬ» И ПРАКТИКА КОНКРЕТНОЙ ПОМОЩИ ТУРИСТАМ
}

Одной из предпосылок стабильного и гармоничного развития туризма является высокое качество туристского продукта. В виду этого стало актуальным создание ассоциации «Турпомощь»

Ассоциация «Объединение туроператоров в сфере выездного туризма «Турпомощь» является некоммерческой организацией, представляющей собой объединение, которое основано на принципе членства юридических лиц, осуществляющих на территории Российской Федерации туроператорскую деятельность в сфере выездного туризма, и действует в целях оказания экстренной помощи туристам в соответствии с законодательством.

Основной задачей Ассоциации «Турпомощь» является забота о каждом туристе, оказавшимся в тяжёлой ситуации, по причине финансовой несостоятельности туроператора.

Ознакомившись с нормативными и учредительными документами ассоциации, можно сказать, что создание Турпомощи позволяет защитить российского туриста не только благодаря механизму финансовых гарантий, но и за счет оперативной помощи пострадавшим путешественникам.

Из Положения об ассоциации среди заявленных функций особенно отмечается:

- обеспечение оказания экстренной помощи туристам в случаях невозможности исполнения, неисполнения или ненадлежащего исполнения 
туроператором обязательств по договору о реализации туристского продукта (в том числе оплата услуг по перевозке и (или) размещению);

- реализация права требования страховой выплаты или выплаты по банковской гарантии, а также право требования к туроператорам;

- осуществление учета взносов в компенсационный фонд на основании содержащейся в реестре информации об общем объеме денежных средств, полученных туроператором, осуществляющим деятельность в сфере выездного туризма, от реализации туристского продукта.

Если турист отправляется в путешествие за рубеж, ему необходимо проверить вступил ли данный туроператор в ассоциацию «Турпомощь». Это можно проверить на сайте «http://www.tourpom.ru/»,написав название компании, сформировавшей туристическую путёвку, в поисковую строку.

Недобросовестное отношение туроператоров к процессу формирования турпродукта ведет к возникновению всевозможных жалоб, претензий и замечаний со стороны недовольных туристов, которые требуют возмещения материального и морального ущерба.

Все жалобы, поступающие от туристов, можно разделить на 4 категории.

Наиболее распространенной категорией являются жалобы на неисполнение турфирмой обещанных услуг или ненадлежащее их исполнение. Часто услуги, которые турфирма предлагает и реализует, не соответствуют тем, которые турист приобретает на самом деле. Разница между предлагаемым турпродуктом и турпродуктом, получаемым туристом, может быть незначительной, а может отличаться коренным образом.

Например, турист по прибытии в гостиницу может обнаружить, что в забронированном номере отсутствует обещанный кондиционер, но может случиться так, что, прибыв в гостиницу, уставший в дороге турист узнает, что номер на его имя зарезервирован не был, а гостиница переполнена. Каждый человек по-своему отнесется к подобного рода несоответствиям. Для кого-то это будет мелкой неприятностью, которая, в принципе, не повлияет на дальнейший 
отдых, а для кого-то подобные обстоятельства могут испортить все дальнейшее пребывание на отдыхе.

Ко второй категории относятся жалобы и претензии туристов о несвоевременном информировании об изменениях в туристической программе. Изменения в программе тура могут быть незначительными (изменение времени вылета), а могут быть серьезными и неприемлемыми для туриста (изменение гостиницы или места отдыха). Турфирма слишком поздно информирует клиента о подобного рода изменениях или не информирует вовсе. Подобные неприятности способны не только испортить отдых, но и отменить его (несвоевременное извещение об изменении времени или места отправки могут привести к опозданию человека пли прибытию его в неправильное место). Результат жалобы на турфирму.

Третья по распространенности категория жалоб включает в себя жалобы туристов на недостоверную и неточную информацию, получаемую от турфирмы. Нередко случается так, что получаемая туристом информация является неточной, а иногда и искаженной. Туриста не осведомляют обо всех деталях тура, о возможных изменениях в программе и расходах.

Последняя категория жалоб связана со стремлением турфирмы к ограничению собственной ответственности за изменения условий тура. В процессе реализации туристского продукта турфирма заключает договор с туристом. Данный договор является соглашением между турфирмой и туристом о предоставляемых (приобретаемых) услугах, правах, обязанностях и ответственности сторон. Поскольку реализуемый тур включает в себя услуги не одного производителя, а нескольких, часть из которых не только находится в другой стране, но еще и не связаны между собой, то турфирма стремится оградить себя от ответственности в результате изменений условий тура по вине этих производителей (ст. 9 Ф3 «Об основах туристской деятельности в Российской Федерации»). Как правило, турфирма имеет типовой договор, согласно которому она имеет как можно больше прав, а турист как можно больше обязанностей. 
Чаще всего жалобы туристов связаны именно с пунктом договора о правах, обязанностях и ответственности сторон. Многие российские туристы, впервые отправляющиеся в путешествие или не сталкивающиеся с какими-либо неприятностями и недоразумениями раньше, относятся к процессу подписания договора недостаточно серьезно и ответственно.

Поэтому, когда возникают различные неприятности и, как следствие, жалобы и претензии, выясняется, что турист не был осведомлен о своих правах и обязанностях, а факт неисполнения турфирмой своих обязательств он подтвердить и доказать не может.

При возникновении вышеперечисленных жалоб, претензий и замечаний турист, недовольный отдыхом, испорченным по вине турфирмы, всегда имеет возможность обжаловать нарушение своих интересов и прав.

Наиболее желательным способом улучшения взаимоотношений между клиентом и турфирмой и способом предотвращения возникновения жалоб и претензий со стороны туриста является саморегулирование.

Одним из способов саморегулирования является включение в штат сотрудников юриста или независимого эксперта, который мог бы консультировать туристов по возникающим вопросам, связанным с договором, разъяснять права и обязанности в соответствии с законодательством РФ как самого туриста, так и турфирмы.

Еще одним способом саморегулирования является сопровождение туристов представителем турфирмы на протяжении всего путешествия или его части. Данный представитель решает на месте возникшие недоразумения и помогает при различных затруднениях.

Если возникшие затруднения не удается решать на месте, туристу необходимо зафиксировать факт нарушения его прав и интересов, и правильно оформить претензию, жалобу, которую впоследствии он предоставляет турфирме, продавшей ему турпродукт. 


\section{Список литературы:}

1. Ассоциация «Объединение туроператоров в сфере выездного туризма «Турпомощь»/ [Электронный ресурс] / Режим доступа: http:// http://www.tourpom.ru/

2. Закон «Об основах туристской деятельности в Российской Федерации». - Издательство: Проспект, 2010. - 24 с.

3. Дурович, А.П. Организация туризма / А. П. Дурович, Н. И. Кабушкин, Т. М. Сергеева // М.: Новое знание, 2003. - 332с. 